\title{
The Poor of Christ in the Roman Church: Role and relevance for today
}

\begin{tabular}{|c|c|}
\hline \multicolumn{2}{|c|}{$\begin{array}{l}\text { Authors: } \\
\text { Horst Müller }{ }^{1} \text { (D) } \\
\text { Jerry Pillay }{ }^{1} \text { (D) }\end{array}$} \\
\hline \multicolumn{2}{|c|}{$\begin{array}{l}\text { Affiliations: } \\
{ }^{1} \text { Department of Systematic } \\
\text { and Historical Theology, } \\
\text { Faculty of Theology and } \\
\text { Religion, University of } \\
\text { Pretoria, Pretoria, South } \\
\text { Africa }\end{array}$} \\
\hline \multicolumn{2}{|c|}{$\begin{array}{l}\text { Project Research Registration: } \\
\text { Project Leader: J. Pillay } \\
\text { Project Number: } 04653484\end{array}$} \\
\hline \multicolumn{2}{|c|}{$\begin{array}{l}\text { Description: } \\
\text { This research is part of the } \\
\text { project, 'African Christianit } \\
\text { and Development', directe } \\
\text { by Prof. Dr Jerry Pillay, } \\
\text { Department of Church } \\
\text { History and Church Polity, } \\
\text { Faculty of Theology and } \\
\text { Religion, University of } \\
\text { Pretoria. }\end{array}$} \\
\hline \multicolumn{2}{|c|}{$\begin{array}{l}\text { Corresponding author: } \\
\text { Horst Müller, } \\
\text { hmuller@nelcsa.net }\end{array}$} \\
\hline \multicolumn{2}{|c|}{$\begin{array}{l}\text { Dates: } \\
\text { Received: } 12 \text { June } 2020 \\
\text { Accepted: } 26 \text { Aug. } 2020 \\
\text { Published: } 17 \text { Dec. } 2020\end{array}$} \\
\hline \multicolumn{2}{|c|}{$\begin{array}{l}\text { How to cite this article: } \\
\text { Müller, H. \& Pillay, J., 2020, } \\
\text { 'The Poor of Christ in the } \\
\text { Roman Church: Role and } \\
\text { relevance for today', HTS } \\
\text { Teologiese Studies/ } \\
\text { Theological Studies 76(1), } \\
\text { a6199. https://doi.org/ } \\
\text { 10.4102/hts.v76i1.6199 }\end{array}$} \\
\hline \multicolumn{2}{|c|}{$\begin{array}{l}\text { Copyright: } \\
\text { (C) 2020. The Authors. } \\
\text { Licensee: AOSIS. This work } \\
\text { is licensed under the } \\
\text { Creative Commons } \\
\text { Attribution License. }\end{array}$} \\
\hline \multicolumn{2}{|l|}{ Read online: } \\
\hline 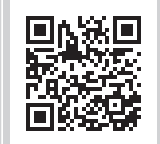 & $\begin{array}{l}\text { Scan this QR } \\
\text { code with your } \\
\text { smart phone or } \\
\text { mobile device } \\
\text { to read online. }\end{array}$ \\
\hline
\end{tabular}

A lay movement known as the Poor of Christ, incorrectly referred to as the Waldensians, started in the Roman Church in 1176 and rapidly spread through Europe despite severe persecution by the church. Through their values and methods, they impacted on the communities where they were present. This article aims to show their role and contributions indicating its impact on the 16th century Reformation and relevance for the church today. It does this by examining selected themes from the Poor of Christ: their life-transforming faith, the strengthening of laity, the equal role of women in ministry, the importance of teaching and living the faith, a focused rather than fenced theology and loyalty to the one Church of Christ. The article also draws reference to the COVID-19 pandemic and explores what we can learn from the Poor of Christ in addressing this situation.

Contribution: This article puts the spotlight on an overlooked lay movement that contributed significantly in preparing the climate for the 16th Century Reformation. Their example shows that the real strength of church is through members empowered to holistically live their faith. The article shows the current relevance of their values and methods.

Keywords: Waldensians; Valdes; Poor of Christ; reformation; laity; COVID-19; women in Church; authority of scripture; authority of Christ.

\section{A short history of the Poor of Christ}

It all started in 1176. A businessman, Valdes ${ }^{2}$ had gathered significant wealth in Lyon, France. He was part of a new group in society - ordinary citizens, not related to nobility or to officials in the Church - starting to play an influential role in society (Asbridge 2011:557-558). Valdes used some of his wealth to commission the translation of the Latin Bible into his mother tongue, Romance. He was fascinated by what he read. The gospel of Jesus Christ touched him. He read about the sending of the disciples by Jesus (Mt 10:5-12) and heard it as his personal call. After giving away all his possessions, he became a wandering preacher in Lyon and neighbouring cities. He focused on preaching repentance, calling people to live a life of following Christ and sharing the New Testament message (Selge 1967:95-96). Soon he had a significant number of people heeding the call - either by becoming wandering preachers themselves or by at least following the repentance call and starting to live a changed life based especially on the 'Sermon on the Mount'. The movement had many names. ${ }^{3}$ We will use the name that they sometimes used to describe themselves: 'The Poor of Christ' (Pauperes Christi), although this name was not used frequently (De Lange 2004:67). We concur with De Lange (2004:58-60) that 'Poor in Christ' captures the essence of their teachings and life style. The name 'Waldensians', by which they eventually became known, is misleading. Audisio (1999) points out that the:

$[T]$ erm 'Waldensian', in fact, was coined by those who persecuted them, designating the heretics by the name of their founder, as is so often the case. The 'heretics', however, never used this name. (p. 3)

Although Valdes played a crucial role as founder and was a recognised authority during his life time, he resisted any hierarchical structures and claimed no special position for himself (Exempla Historica 1984:83-84). Because of that, very little is known about him - not even key biographical

1. When speaking about the church in which the Poor of Christ existed, we refer to it as the Roman Church, rather than the Roman Catholic Church. At that stage, European Christianity had split into two: The Western Church with Rome and the Eastern Church with Constantinople as its centre. The Poor of Christ existed within the Roman Church only. For them, there was only one Church - the one they knew, which was headed by the pope in Rome.

2.We use 'Valdes' as name form, as it is regarded as the most likely form that the name had in his dialect (ed. De Lange \& Schwinge 2003:175). Other forms are Vaudes, Waldes and Valdesius. The first name 'Peter' or 'Petrus' first appears in 1368 and was only given long after his death.

3.Other names such as Poor of Lyon, Lombards, Sandalwearers and Waldensians (Frank et al. 1999:23) feature regularly. 
information such as his date and place of birth, nor the place, date or even the year of his death (Exempla Historica 1984:73). The strength of the Poor of Christ did not lie in his strong leadership, but in his emphasis on thorough teaching and instruction, which was received and passed on by many (Frank, De Lange \& Schwinge 1999:15). Valdes was the initiator, but many became the multipliers. Within 30 years, they had spread from Spain in the South to the Baltic Sea in the North.

The movement very soon came into conflict with the Roman Church because the preachers were lay people, ministering without being called by the church. Valdes travelled to Rome to obtain permission from Pope Alexander III, who granted it subject to the approval of the local bishop. When local bishops denied permission, Valdes took a decision that shaped the movement from there onwards. Based on Acts 5:29 'We must obey God rather than human beings', he and the men and women with him continued their ministry. The layman Valdes, based on his own reading of the New Testament and the teachings of Jesus, came to the conclusion that the authority of scripture supersedes that of doctrines and that the authority of Christ supersedes that of the pope.

This was a crucial turning point in church and doctrinal history. In the understanding of the Roman Church, the pope as representative of Christ was the ultimate authority, and the doctrines of the church were the authoritative interpretation of scripture. A lay person now challenged the church and its authority, referring to the authority of Christ as Lord of the Church and scripture as the source of all doctrine. These two principles eventually developed into the Sola Scriptura and the Solus Christus of the 16th century Reformation, ${ }^{4} 350$ years later.

This approach of Valdes resulted in him and his movement being excommunicated. In 1184, the French bishops demanded that the Synod of Verona add them to the list of heretical movements (Tourn 1983:23). Audisio (1999:16) establishes that this was not because of the content of their teaching, but for refusing to obey church authority.

Under Pope Innocent III (1199-1216), there was a period of negotiation, and attempts were made to bring the movement into obedience. It partly succeeded when Durand of Huesca, a leading figure of the Poor of Christ, obtained permission from Innocent III to form an order, the Poor Catholics (Frank et al. 1999:41). This order was tasked to do the same ministry as the Poor of Christ, hoping that the latter would all join this order. Announcing their founding and their approval by the Holy See, Innocent III wrote to the Archbishop and bishops in Tarragona in 1208 (Wakefield \& Evans 1991):

We, therefore, ... order by apostolic letter that if you shall receive a similar vow from other brothers [Poor of Christ], you shall reconcile them to ecclesiastical unity by an oath like this, and you

4.The 16th century Reformation had four key concepts forming the basis of its theology: Solus Christus (Christ alone), Sola Scriptura (Scripture alone), Sola Gratia (Grace alone) and Sola Fides (Faith alone). shall make it known by proclamation and in other ways that they are truly Catholic and rightly faithful, keeping them under God free from all scandal and infamy; and you shall mercifully aid them with testimonial letters and other assistance, for the sake of God. (pp. 223-224)

A year later, the pope complained that the Poor Catholics were not successful in bringing back the Poor of Christ (Wakefield \& Evans 1991:226-227), and harsher methods were needed. The dialogue ended. This was confirmed during Lateran IV in 1215, which in Constitution Three stated: ${ }^{5}$

We excommunicate and anathematize every heresy raising itself up against this holy, orthodox and catholic faith which we have expounded above. We condemn all heretics, whatever names they may go under. They have different faces indeed but their tails are tied together inasmuch as they are alike in their pride. (Constitution Three, Lateran IV, 1215)

Their 'pride', the refusal to submit to authority, was sufficient to declare them heretic.

Lateran IV introduced violence as a legitimate, sanctified method to combat heresies, promising indulgence to all who take the cross and gird themselves up for the expulsion of heretics (Decree three). This was the beginning of a most brutal persecution of the Poor of Christ by the Inquisition, lasting three centuries. Despite this persecution, the Poor of Christ continued their ministry. They developed a system of roaming preachers and teachers, Meister and Meisterinnen, who were well organised and had a detailed travel plan which was strictly and punctually followed so that those visited could be ready and waiting without drawing unnecessary attention (Tourn 1983:74).

The main source of information on the movement is the Inquisition reports. They show how effective the underground movement had become. In quite a few places where they were found, executed and thought to be eradicated, a subsequent Inquisition 50 years later (two generations!) again found many followers. This is, firstly, because everybody had not been discovered previously and, secondly, because of the system of teaching used: parents taught their children, and the families were then visited on a regular basis by the wandering master responsible for their region (Molnár 1993:147-148). Even though some were killed, there were others who continued the ministry. Known as the people with the little books, they carried their Bibles hidden in their garments (Audisio 2009:32). As their Bibles were confiscated and burnt, they depended on memorising scripture. The New Testament was their handbook, and the teachings of Jesus were the core of their life-transforming message. This resulted in them being respected by the population as trustworthy people of integrity (Patschovsky 2011:159-160).

They treated men and women as equal. Women were teachers and preachers, a matter that the inquisitor Stephen of Bourbon complains about (Molnár 1993:44). They lived in a patriarchal environment in both church and society. Because of their intense study of the New Testament, it would have

5.https://www.papalencyclicals.net/councils/ecum12-2.htm. 
been obvious for them to follow 1 Corinthians 14:34-36 and 1 Timothy 2:11-15, where women are forbidden to preach or teach. Yet, they ascribed higher authority to the way that Jesus treated women and sent them as first messengers at Easter (Mk 16:6f; Mt 28:5-8; Jn 20:16-18) than to Paul's statements, which shows that they interpreted scripture based on the teachings of Christ. Martin Luther, much later, followed this approach in stating that the Word of God in scripture has to be found in 'das was Christum treibet' (WA DB 7:25 1522) ${ }^{6}$ - that which promotes Christ.

Their ministry was holistic and life-transforming. They did not only preach and teach but also counselled and treated the sick (Biller 1982:55-77). As a result, they were welcomed by the population in many parts of Europe, despite being declared heretics.

The Poor of Christ had an undivided loyalty to the Roman Church as the Church of Christ. Unlike other 'heresies' such as the Cathars, who saw themselves as the true church, and the Roman Church as totally wrong, the Poor of Christ remained loyal to the church despite the severest persecution by their church. They distinguished between the Church with Christ at its head and the ordained people in authority, including the pope, who might abuse and misuse their position. They criticised these abuses, but they did not turn their back on the church to establish their own movement. Because of this, they continued to influence the church from inside, contributing to the Reformation at the beginning of the 16th century.

Maps showing their presence in the Holy Roman Empire between 1176 and 1532 (Frank et al. 1999:12) indicate their presence especially in the German territories that became the home ground to the 16th century Reformation. A comparison between the regions of their activities and the regions that were at the forefront of supporting the Reformation at the Diet of Speyer (1529) shows a substantial overlap (Müller 2020:189-192). Historical contextual analyses show their influence in free imperial cities and in those regions where important role-players of the Reformation, such as Johan von Stauptiz, grew up. Consolidated with the reports of the contributions by the lay people from Nuremberg and other regions known for the presence of the Poor of Christ, it becomes clear that this lay movement had a significant impact in preparing the scene for the 16th century Reformation, a matter that deserves much more attention in reformational studies.

\section{The Poor of Christ as example for church today}

The task of history is not only to study the past but also to understand the present and shape the future. By critically looking into our current context and bringing into it lessons learnt from the Poor of Christ, history becomes relevant now.

6.Luthers Werke im www, Weimarer Ausgabe, viewed 15 May 2020, from http:// luther.chadwyck.com/?instit1=upretoria\&instit2=welcome.

7.This is dealt with in detail in the study of Müller (2020).
Christianity in many former Christian strongholds in the Western world is on the decline. The term 'Post Christian' is used by more and more church historians to describe our times. Tusting (2004) calls her study: 'Congregational Studies in the UK: Christianity in a Post-Christian Context', and Granberg-Michaelson (2013) names his book From Times Square to Timbuktu: The Post-Christian West Meets the NonWestern Church.

The German Protestant churches, home of the initial Reformation explosion, had a study done, Kirche im Umbruch, on why the German church (both Protestant and Roman Catholic) is so drastically declining. The webpage of the Evangelische Kirche in Deutschland (EKD) states:

Wie kann die evangelische Kirche auch in Zukunft Menschen von sich überzeugen? Sie muss vorhandene Strukturen kritisch prüfen, neue Angebote - vor allem für junge Erwachsene entwickeln und frische Impulse setzen. ${ }^{8}$

The main focus is on the following questions: What needs to be done differently? Where do we need to change our approach? They see the answer in re-looking at structures and finding new things to offer, especially for young adults, giving fresh impulses.

Based on what we learn from the Poor of Christ, it is the lifetransforming message of Christ which encompasses all aspects of life: Spiritual matters and daily encounter in the community and workplace is what makes church authentic. When this life-transforming message, taken for granted, is ignored and no longer passed on from generation to generation, the church can only decline. Merely offering new impulses and changing structures does not create authenticity. Developing programmes to attract people cannot replace authenticity.

\section{Focus on the life-transforming message of Christ}

The Poor of Christ did not spread because they had a strong central head office that developed strategies and programmes, structures that are today often thought to be essential. The laos, the people of God, were the essential carriers of God's Word. Because of the severe persecution, they could not afford to merely honour tradition. Their Meister and Meisterinnen were no overseers policing the members, keeping them in line, but trainers, teachers and supporters to the families and communities, strengthening their resolve to live their faith in extremely difficult circumstances.

We can learn from the history of the Poor of Christ to ask the right questions:

- Are we as church still busy with our core function - to proclaim the life-transforming message of Christ and to assist Christians to live out this faith?

- Can this life-transforming message be heard clearly in our proclamation and seen in our lives?

8.viewed 15 April 2020 , from https://www.ekd.de/kirche-im-umbruch-projektion2060-45516.htm. 
- Do we lead our people, the laos, laity, to maturity, to stand on their own feet, able to answer for their faith and pass it on to their own children and grandchildren?

Africa provides a fascinating example of this happening. Unlike in Europe, Christianity in Africa is on the increase. South Africa's increase is low. Maluleke (Ross et al. 2018) shows a slight annual growth rate of Christianity in South Africa in the period 1975-2015 of 2.15\%. Independent and Charismatic churches show the largest increase, whereas the Protestant group showed the largest decline from a share of $28.7 \%$ in $1975-19.25 \%$ of the population in 2015. In other parts of the sub-Saharan Africa, a different picture emerges. Nyomi, in discussing Protestants in the region (Ross et al. 2018), shows the growth of Protestants as a portion of the total population rising from $9.3 \%$ to $16.6 \%$, with the strongest growth in Eastern Africa (from 7\% to 18.7\%). In East Africa, Ethiopia and Tanzania deserve a closer look.

Ethiopia is home to one of the oldest churches globally, the Ethiopian Orthodox Church (EOC), and also to the young Protestant churches. Eshete (Ross et al. 2018:156-158) discusses the development of Christianity in that country. As the Ethiopian empire expanded, the emperors ensured that the EOC expanded with it. In relation to the total population of the empire, it remained at a constant $39 \%$. The Protestants, Pentecostals and Evangelicals together, however, were a mere $6 \%$ of the population in 1975 ; but in $2015,42 \%$ of the population belonged to them (Ross et al. 2018:158).

Eshete gives as a reason for the comparatively poor performance of the EOC that Emperor Haile Selassie wanted to modernise the EOC, but 'both the lower-level priests and its upper-echelon hierarchy, was resistant to change' (Ross et al. 2018). He then points out:

Above all, a radical move made by the Emperor was the instrumental role he played in the publication in 1961 of the Bible in Amharic, the local language. This had huge unintended consequences, as it shifted the knowledge centre of the source of the Christian faith from a special priestly elite to the ordinary people - a factor that inadvertently undermined the historic church. The availability of the translation of the message into the national language is one of the crucial factors that facilitated the spread of the Evangelical faith in Ethiopia. (p. 158)

This is almost like a mirror of the Poor of Christ and the Roman church of their time. The laos get access to the Bible in their mother tongue and start living their faith based on their interaction with scripture. The established church resists reform and loses credibility.

Similar observations can be made regarding the growth and spread of Christianity in Tanzania, described by Gitau (Ross et al. 2018:121-123). Here, all Christian Churches have experienced significant growth in the period between 1975 and 2015. Gitau gives as a reason the translation of scripture into local vernacular and the emphasis on teaching in all denominations. "The supply of the printed Scriptures, firsttime writing of grammars, liturgies and catechism excited inland communities so that evangelism progressed quickly during the colonial decades' (Ross et al. 2018:122).

As with the Poor of Christ, the availability of scripture in the mother tongue and equipping the laos to read and understand the message meant that the Christian faith could become a lived faith, leading to its rapid spread in all denominations promoting this. This then also links up with the next important matter.

\section{Strengthening laity}

When speaking about the Reformation and its important role players, immediately the name of theologians come to mind. Although the theologians were the key to putting on paper the theological statements, the Reformation would have stayed a theological debate, had it not been for the strong basis of support from knowledgeable lay people. As can be seen from the Diet of Speyer (1529) and Augsburg (1530), the lay people did not only represent secular authority, but to a large extent were fully involved in the theological debate, contributing from their own knowledge and thinking (Müller 2020:190).

Lay is often misunderstood as meaning theological illiteracy. This clearly is not the case when looking at the Poor of Christ. The training of their lay Meister and Meisterinnen was intense and lasted for 10-12 years (Lerner 1986:243). They in turn did not keep their knowledge to themselves, but passed it on to the people that they cared for. The ministry of the Poor of Christ was empowering the laity.

As pointed out with regard to church growth in Ethiopia and Tanzania, when lay people are empowered to study scripture, it brings in a whole new dynamic into church life. Wellequipped lay people are also the teachers to young children either as parents or through children's ministries, providing them with a firm foundation.

For any church to be resilient and growing, it needs to have a strong focus on the training and equipping of lay people. They need to be able to answer to what they believe. This goes much deeper than memorising a catechism and reciting the 'right' answer when asked.

Both the Heidelberg Catechism ${ }^{9}$ and Luther's Small Catechism ${ }^{10}$ follow the pattern of asking questions and then providing the answer. The intention is that Christians must know what they believe. However, when question and answer are merely recited without understanding, it becomes a futile exercise. For that reason, it is important that critical thinking and reflection is encouraged. As with the Poor of Christ, significant emphasis must be placed on the study of scripture. Critical reflection on the teachings of one's own denomination must be encouraged. Lay members, equipped and encouraged to think critically about their own denomination, are not a threat, but contribute to the resilience of a faith community, helping it to focus on what really matters.

9. Heideliberg Catechism, viewed 10 May 2020, from http://www.heidelberg catechism.com/en/lords-days/32.html.

10.Luther's Small Catechism, viewed 10 May 2020, from http://bookofconcord.org/ smallcatechism.php. 
With the Poor of Christ, the training happened in the homes. It was necessitated by the danger that they operated under. However, the strong developed laity carried the movement through the long-lasting extremely difficult times.

The 2020 COVID-19 lockdown in South Africa brought with it particular challenges for the faith communities. All religious gatherings were banned. Holy Week, Easter and Pentecost could not be celebrated in the churches. Initially, there was huge resistance, because congregating to pray, worship and celebrate is an integral part of the Christian faith. Churches were left with three options:

- not to have any worship services, which was unthinkable

- have virtual services recorded and accessed via the Internet. This option was followed by most churches with sufficient IT infrastructure.

- have services in the homes, led by a member of the household. Denominations with an exclusive focus on priest-led services battled with this situation. Those with a strong emphasis on lay development and a tradition of house groups could adapt to these circumstances much easier.

It became even trickier in respect of Holy Communion. With the COVID-19 lockdown, debates started as to what to do regarding Holy Communion, as it is an integral part of the life of most denominations. The responses varied, based on the theological understanding of denominations.

The Roman Catholic doctrine requires that an ordained priest does the consecration. The Archbishop of Johannesburg wrote to his diocese: 'The Holy Father has granted in the Decree in Time of COVID-19 the faculty to all priests to celebrate this Mass ALONE and omit the procession to the place of repose' (viewed 14 May 2020, from https:// www.radioveritas.co.za/images/PDFs/Response_to_the_ National_Lockdown_Covid-19.pdf).

The Anglican Church in Southern Africa also requires an ordained priest for the celebration. It had the following post on their webpage, by Retired Bishop Geoff Quinlan (emphasis in the original):

I have begun celebrating the Eucharist on line in a way that allows participants to make their communion. I use the full Eucharistic service with the Consecration Prayer and ask participants to have bread and wine with them at home for consecration. In the Eucharistic prayer I then consecrate, by intention, the bread and the wine before me and also that in the homes of communicants.

One Lutheran denomination issued a guideline to all members on how to celebrate communion at home, without the presence - virtual or real - of a pastor. The document, issued on 07 April 2020, states: ${ }^{11}$

We are in extraordinary times. Church Council of NELCSA ${ }^{12}$ has agreed that during this time we should find ways of making it

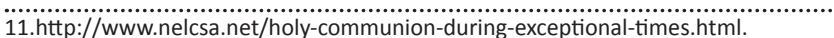
12.Northeastern Evangelical Lutheran Church in South Africa. possible for our members to celebrate communion in their homes. There is no way that the pastors can visit all the homes apart from the fact that it now would be in contravention of the lockdown. We therefore encourage families living together in their homes, as well as singles, to not only hold devotions, but also to celebrate communion.

This document is heavily influenced by the lessons learnt from the Poor of Christ. While theologians around the world were debating on whether virtual communion, where a priest celebrates it in a live broadcast, and parishioners participate in their homes, can be regarded as 'real', it asked: 'What does the New Testament say?'. The guiding text was John 6:35-58, where Jesus, time and again, is asked to explain how one can eat and drink his body and blood, and every time, his answer is: Eat and drink - just that, without giving any explanation. From this, the authors concluded that in the time of lockdown, our task is not to ask: Is it possible, but to make it possible that people eat and drink, partake in the body and blood of Christ. Thinking of the Poor of Christ, who in times of exclusion celebrated in their homes, they proposed that during this lockdown period Christians should be encouraged to celebrate communion in their homes as well. Following the example of the Poor of Christ to equip the laity, the handout referred to above was prepared to guide and instruct the lay leaders in the household. The importance to participate in the body and blood of Christ in these challenging times outweighed all doctrinal reservations.

The lockdown situation made it very clear that the resilience of a church does not depend on how many priests there are, but on whether the laos, the people, understand themselves to be fully Church - even without an ordained priest or pastor present.

\section{The equal role of women in the Church}

Based on 1 Corinthians 14:34f and 1 Timothy 3:11-15, some denominations currently do not ordain women. By this decision, many other New Testament instances are ignored where women played a very important leadership and proclamation role. This is especially true for the various Easter morning reports, where time and again women are first commissioned to proclaim to the disciples the good news that he has risen (Mk 16:6f; Mt 28:5-8; Jn 20:16-18).

Part of the resilience of the Poor of Christ was because of the role of the Meisterinnen, who, in a male dominated society, could teach and train the mothers who passed on this knowledge to their children, much better than a man could. Sadly, in most Protestant churches, the equal role of women was not recognised and practised, to the detriment of church and society. To ban half of the membership from developing their proclamation skills despite the overwhelming Easter testimonies is, simply put, foolishness and depriving those churches of a major asset. 
There are some denominations that do treat women as equal. Kaunda and Phiri (2016) say about women in the Africa Initiated Churches (AIC):

While acknowledging that women are marginalised in some AICs, the majority of these churches recognise the spiritual virility, or vitality operating in women who are endowed with the power of the Holy Spirit. (p. 2)

They point out that because of the emphasis on the working of the Holy Spirit, who does not discriminate against women, women can be founders of congregations and play leading roles in the AIC much more readily than in traditional churches. 'This may explain why there are also a good number of the Spirit-type churches which are founded and led by women even among Zulus, despite being patriarchally oriented societies' (Kaunda \& Phiri 2016:5).

Haddad (2016:158) focuses on churches of European origin and relates how missionary women introduced schools for girls and women, with the main focus on teaching them skills around traditional roles for women. Thus, while uplifting women, it aligned them according to the patriarchal traditions. They met on a weekly basis, also for prayer, and generally became known as the manyanos. Such Women's leagues or Prayer Women or Women in Uniform today form an integral part of many churches in South Africa. Although they play an important role, in many cases it is not an equal one. The uniform speaks for this. Haddad explains that the uniform originally was a sign of dignity and liberation for women in a male-dominated environment, because it showed that they had a place and function in church (Haddad 2016:169). However, the uniform is also seen by more and more modern women as a tool of oppression (Haddad 2016:170), part of the old system to 'keep women in place'.

We learn from the Poor of Christ that gender cannot be allowed to be a disqualifier, especially not when it comes to teaching and nurturing the talents of the people. Whoever has a gift should be encouraged and supported to develop that gift.

The church should be that place, where more than elsewhere Galatians 3:28 is put into practise: 'There is neither Jew nor Gentile, neither slave nor free, nor is there male and female, for you are all one in Christ Jesus'. And this, we certainly learn from the Poor of Christ.

\section{Teaching, learning and living the faith}

This links up with the role of laity mentioned above. A strong point of the Poor of Christ was that they did not only know the teachings of Jesus, but that they put them into practise, thus gaining respect from their communities.

Sadly, in our time religion is used as a means to gain trust and then leech money out of people. Lateran III, decree three (https:/ / www.papalencyclicals.net/councils/ecum11.htm accessed on 29.05.2020) already was addressing the issue of excessive wealth of bishops and prelates. In that time, people had no choice but to pay church taxes, and apart from that, fear of hell and damnation was further used to extract monies from them. In modern South Africa, people chose where to go. Those attending are not victims of a system forced onto them. Yet, current court cases, such as against Prophet Bushiri, ${ }^{13}$ who is regarded as one of the wealthiest preachers in Africa, show that they have large followings and that poor people are willing to give huge offerings in support of them.

Kgatle (2017) asks the question why people within the churches of such prophets remain loyal to them, even if it is to their own detriment. He states that: 'Most of the pastors in Neo-Pentecostalism reject such a training (theological training for ministry), let alone academic activities of theological field' and sees in this a sign of anti-intellectualism. He sees the desire for miracles as a main reason why middle and upper class people follow these prophets. His recommendations to counter this focus on creating more accountability, which includes reporting to the South African Council of Churches (SACC). We are of the opinion that it will not really make a difference, because these prophets do not adhere to any rules and regulations.

We agree with Ramantswana (2019) who argues 'that neoprophetic churches are tapping into people's longing for the fresh divine word to speak directly into their personal situations'. The adherents of these prophets go there out of their own free will.

We can learn from the Poor of Christ: the solution to this abuse does not lie in secular authorities protecting the people against heresies through laws. This was the approach followed by the Roman Church. The laws and decrees did not stop the abuse of authority, but in the process good movements and people were banished and even executed. Kgatle refers to the anti-intellectualism of Neo Pentecostalism. Instead of protecting the people/laity through laws and rules, the solution is to equip them through sound teaching. Lay people need to have a firm knowledge of scripture, which will become the 'fresh divine word speaking into their personal situations', as was the case with the Poor of Christ. Sound teaching will help people to better discern when they are being misled. Many of those attending these strange services come from established churches where they should have received such a solid foundation. This begs the question as to whether they were taught to recite, or empowered to think critically and understand and challenge what they were taught.

\section{Focused, rather than Fenced theology and dogma}

The terms 'focused' and 'fenced' theology and dogma are coined by us, based on the observations of the Poor of Christ and the Roman Church in which they existed.

13.viewed 21 May 2020, from https://www.timeslive.co.za/news/south-africa/2019 11-29-prophet-bushiri-to-stand-trial-next-year-on-fraud-and-money-launderingcharges/. 
Fenced theology and dogma states in as much detail as possible what the Church believes, leaving little room for interpretation and no room for dissent. The Roman Church over centuries developed such doctrines to define itself and to define who heretics were. The decrees and dogmas issued in view of the Poor of Christ served as fences in order to clearly state who is inside and who is not.

Focused theology has a focal point which is non-negotiable. In the case of the Poor of Christ, this focal point is Jesus Christ as revealed in scripture. Only Christ defines Church, and therefore, Church is where Christ is the focal point. If that focus is lost, one literally 'misses the point' and Church loses its core function. When that focus is maintained, there is room for differing interpretations on almost every other matter.

The resilience and spread of the Poor of Christ can be ascribed to this focused approach. In the beginning, it was a conscious decision by Valdes and the early preachers and teachers to focus on Christ and his message. Because of the severe persecution, the movement could never develop an extensive system of dogmas and theology. They had to rely on what they could memorise, which was the New Testament and its core message. This is what was also taught to each new generation. Thus, the persecution forced them to stay focused and ensured the continuation of the movement with its core message for more than 300 years.

The 16th century Reformation Church in its early phase was focused - best summed up in the sola scriptura, sola fide, sola gratia, solus Christus explaining the core of its faith. It soon moved into the 'fenced mode'. The Augsburg Confession (CA) of 1530 already shows this shift happening. Although it clearly states what Protestants believe (focus), it starts erecting fences to indicate who is and who is not acceptable. CA X states: ${ }^{14}$ 'Of the Supper of the Lord they teach that the Body and Blood of Christ are truly present, and are distributed to those who eat the Supper of the Lord; and they reject those that teach otherwise'. The first fence is erected by rejecting those who have a differing view of communion. This was the start of the splitting up of the Reformation Churches.

As this article is being completed, the impact of the COVID-19 lockdown in South Africa is becoming increasingly visible. The economy had come to an almost complete standstill. As a result, many day labourers are without an income and large portions of the population are facing severe hunger. In this crisis situation, many churches adopted the 'focused' approach, and based on the common belief in Christ, joined hands to reach out to these people in need. Just one of many examples is quoted here, reported in the Mercury Newspaper on 14 April 2020 (viewed 13 May 2020, from https://www. iol.co.za / mercury/news/kzn-churches-pledge-r1-millionto-assist-with-covid-19-relief-efforts-46679262):

14.Citations from the Confessio Augustana, viewed 18 May 2020, from http:// bookofconcord.org/augsburgconfession.php.
Durban - Churches, Christian associations, ecumenical networks and ministers' fraternities have banded together to pledge R1 million towards Covid-19 relief efforts in KwaZulu-Natal. ... Chairperson of the KwaZulu Natal Church Leaders Group and Chairperson of the KZN Inter Religious Council, Cardinal Wilfrid Napier said, "This is a powerful gesture of inestimable symbolic value. We gladly notify you that the Churches across the KwaZulu Natal province, are pledging R1 million to the relief emergency in our province'. ... 'All of this is undergirded by an inter-denominational space for prayer and reflections on the life-affirming theology of care in the face of the pandemic.'

The crisis brings together people from different denominations in prayer and action. Fences come down and churches again focus on the core, to the benefit of society at large.

Another example caused by the COVID-19 crisis is that members of households belonging to different denominations now worship together. Because of this crisis the fences came down, and the combined focus on Christ as head of the Church was sufficient for celebrating together. Without the crisis, the fences would have prevented it. Difficult times force believers to distinguish between what really matters and what matters less.

We believe that communities will immensely benefit if denominations, also in normal times, learn to be focused rather than fenced in their thinking and action. For that to happen, church leadership needs to ensure that the core message is not taken for granted. It must be taught and valued as something that is shared by the large body of churches and not only by their denomination.

A focused theology does allow for specific doctrinal developments. When focused on Christ and scripture, there is a huge scope for differing interpretations and resulting doctrines. In a focused approach, the diversity does not weaken, but rather strengthens the resilience of the church. It encourages the critical self-reflection and mutual learning across denominational divides.

\section{Loyalty to the one Church of Christ}

The German wing of the Poor of Christ was part of the society and existed within the church, despite being persecuted by it. During the Reformation, people like Johan von Staupitz and Phillip Melanchthon supported the reformational thinking, but resisted a split of the Church of Christ into denominations. When the split did happen, it became a continuous process of further splitting up of the Protestant movement. It was only in the 20th century that the awareness of the one global Church of Christ started to gain ground again in the rise of ecumenical bodies.

In South Africa, there are various ecumenical bodies that demonstrate the awareness of one-ness. The Church Unity Commission was started in 1968. Duncan (2011) lists the participating churches as:

Church of the Province of Southern Africa the United Congregational Church of South Africa, the Evangelical 
Presbyterian Church in South Africa, the Methodist Church of Southern Africa, the Presbyterian Church of Southern Africa and the Reformed Presbyterian Church in Southern Africa. (p. 19)

With time, other Protestant churches were invited as observers and later as members. It is a strong ecumenical body, but still excludes the Evangelical and Pentecostal Churches. The intended full unity was never achieved. Duncan (2011) states:

In the general sphere of ecumenism, a significant issue relates to the manner of approach to Church unity. The predominant approach tends to be protectionist, i.e. how can churches unite by retaining as much of their historical traditions as possible and making the minimum of concessions to other traditions? This approach is focused on maintaining the past and allowing it to dominate the present and future. (p. 37)

The focused approach opened the door for discussion. The fenced approach prevented full unity. The focus on Christ allowed the Poor of Christ to stay loyal to the Church, even though they had significant doctrinal disagreements on issues such as Purgatory and the role of laity. What can such a focus on Christ and loyalty to his Church mean in South Africa with its countless denominations?

The current COVID-19 crisis provides an example of what it can mean. The South African Council of Churches (SACC) made a passionate call on all its member churches to work together to address challenges arising from the lockdown. Within the first weeks of the lockdown, a 'SACC Local Ecumenical Action Network (LEAN) - Starter Pack'15 was sent to all member churches. It defines LEAN as:

[A]n existing network (e.g. fraternal, alliance etc.), or new group of 10 or more churches from a local neighbourhood - from different denominations - that have connected with each other to collaborate on local action during the Covid-19 pandemic in South Africa.

During the weeks that followed, it became increasingly clear how difficult it was to get LEANs going, because of lack of ecumenical interaction on a local level. From the oral reports given at meetings, it emerged that some LEANs consisted of clergy from one denomination only, ignoring all the other denominations in the area. Fortunately, as the crisis grew, more and more clergy realised the benefit of such co-operation. LEANs could make a significant impact in their areas, because of the combined effort of all the churches.

\section{The positive impact Church can have on society}

The Poor of Christ impacted on society mainly through their authentic, holistic approach. They did not develop a strategy on how to do this. Rather, they heard the message of Jesus and put it into practice. Their faith was more than just a part of their life - their life and their faith were one. They were 15.Viewed 20 May 2020 , from https://churchinaction.org.za/index.php/resourcestools/church-leaders/lean. accused of pretending to be merchants or doctors, or teachers in order to cover up for what they were really up to (Frank et al. 1999:35). The reality, however, was that there was no separation between what they believed, their profession and what they lived. We learn from the Poor of Christ that the most powerful impact that Christians can have is when they, in their ordinary profession, are people of integrity and reliability.

This one-ness of faith and life, authenticity and integrity is addressed by Pillay (2017) under the topic 'Spirituality':

Spirituality is the pattern by which we shape our lives in response to our experiences of God as a very real presence in and around us. To be spiritual is to take seriously our consciousness of God's presence and to live in such a way that the presence of God is central in all that we do. Such spirituality turns to the world, not away from it. (p. 5)

Our daily lives and encounters with people around us should reflect the holistic impact of our faith - be it as a pastor, a sales person, a teacher, a pensioner, or a craftsman. When we are 'Poor in Christ', dependent on Christ and living from him, we can and will have an impact on society as the Poor of Christ had. As Pillay (2017) expresses it:

$[A]$ ny piety that appears to be content with a personal relationship with Jesus, and which shuns or belittles the horizontal dimension of discipleship, is suspect. Any spirituality that advocates a withdrawal from what is going on in the world is contrary to Christ's spirit. (p. 5)

The COVID-19 crisis results in this spirituality being put to the test. As the lockdown in South Africa commenced, it was clear that many people would suffer - not so much from the virus, but from being without income and food. While government started planning to deal with this, many church communities did not wait, but sprang into action where they were.

Verbal reports back at the weekly Zoom meetings of SACC church leaders show that many local ecumenical support projects never stopped, despite contravening lockdown rules. Obedience to Christ superseded obedience to the lockdown laws. The need was apparent and hunger cannot be put on hold till laws and strictures are in place. The months to come will further put the Church to the test, as all indications are that the misery will increase for quite a while.

\section{Conclusion}

The unknown Poor of Christ through their ministry and values had a significant impact on the 16th century Reformation. Similarly, the biggest difference in the current crisis and in society will not be made by large-scale campaigns by a few prominent individuals, but by a large number of (unknown) Christians living out their faith, following the example set by Christ and making a difference where they are amongst the people with whom they come in contact, acting not divided into denominations, but together, serving 
Christ. Just as the Poor of Christ had a significant impact on preparing the climate for the 16th century Reformation, Christians in this way can have a significant impact on how the COVID-19 crisis plays itself out.

\section{Acknowledgements Competing interests}

The authors have declared that no competing interest exists.

\section{Authors' contributions}

All authors contributed equally to this work.

\section{Ethical consideration}

This article followed all ethical standards for a research without direct contact with human or animal subjects.

\section{Funding information}

This research received no specific grant from any funding agency in the public, commercial or not-for-profit sectors.

\section{Data availability statement}

Data sharing is not applicable to this article as no new data were created or analysed in this study.

\section{Disclaimer}

The views and opinions expressed in this article are those of the authors and do not necessarily reflect the official policy or position of any affiliated agency of the authors.

\section{References}

Asbridge, T., 2011, Die Kreuzzüge, Klett-Cotta, ISBN 978-3.608-94648-2.

Audisio, G., 1999, The waldensian dissent: Persecution and survival, c. 1170-c. 1570, Cambridge University Press, Cambridge.

Biller, P., 1982, 'Curate infirmos: The medieval Waldensian practice of medicine', Studies in Church History/l19,55-77. https://doi.org/10.1017/S042420840000930X
De Lange, A., 2004 'Valdes, die ersten Waldenser und die Mystik', in M. Delgado \& G. Fuchs (ed.), Die Kirchenkritik der Mystiker; Band 1: Mittelalter; Studien zur Christlichen Religions- und Kulturgeschichte, pp. 53-67, Academic Press, Fribourg.

De Lange, A. \& Schwinge, G. (Hrsg), 2003, Beiträge zur Waldensergeschichtsschreibung, Waldenserstudien Band 1, Verlag Regionalkultur, Heidelberg, ISBN 3-89735-235-4.

Duncan, G., 2011, 'The Church Unity Commission: South African ecumenical perspectives on ministry (1968-1983)', Studia Historiae Ecclesiasticae 37(1), 19-38.

Fischer, M., 1984, 'Petrus Waldus' in Exempla Historica, Epochen der Weltgeschichte in Biographien, 14, Mittelalter: Päpste, Kirchenfürsten, Ordensgründer, FischerTaschenbuch-Verl, 1984. pp. 72-84.

Frank, G., De Lange, A. \& Schwinge, G., 1999, 300 Jahre Waldenser in Deutschland Die Waldenser-Spuren einer europäischen Glaubensbewegung, WMV, Werbung, Marketing und Verlag GMBH, Bretten, ISBN 3-9806510-1-0.

Granberg-Michaelson, W., 2013, From Times Square to Timbuktu: The Post-Christian West meets the Non-Western Church, William B. Eerdmans Publishing Company, Grand Rapids, MI.

Haddad, B., 2016, 'Church uniforms as an indigenous form of Anglicanism: A South African case study', Journal of Anglican Studies 14(2), 156-171. https://doi. org/10.1017/S1740355315000224

Kaunda, C.J. \& Phiri, I.A., 2016, 'African instituted churches pneumatology and gender justice in the work of Gc Oosthuizen: An African feminist pneumatological perspective', Scriptura 115, 1-12. https://doi.org/10.7833/115-0-1290

Kgatle, M.S., 2017, 'The unusual practices within some Neo-Pentecostal churches in South Africa: Reflections and recommendations,' HTS Teologiese Studies/ Theological Studies 73(3), a4656. https://doi.org/10.4102/hts.v73i3.4656

Lerner, R.E., 1986, 'Historiography: A case of religious counter-culture: The German Waldensians', The American Scholar 55(2), 234-247.

Molnár, A., 1993, Die Waldenser: Geschichte und europäisches Ausmaß einer Ketzerbewegung, Freiburg im Breisgau, Basel, ISBN: 3-451-04233-9.

Müller, H., 2020, The Poor of Christ and their significant impact on setting the scene for the 16th century reformation, viewed 01 June 2020, from http://hdl.handle. net/2263/74736.

Patschovsky, A., 2011, Ketzer, Juden, Antichrist. Gesammelte Aufsätze zum 60 Geburtstag von Alexander Patschovsky, Bibliothek der Universität Konstanz, Konstanz, viewed 31 March 2020, from http://nbn-resolving.de/urn:nbn:de: bsz:352-opus-6734.

Pillay, J., 2017, 'Reformation and transformation today: Essentials of reformation tradition and theology as seen from the perspectives of the South', HTS Teologiese Studies/Theological Studies 73(3), 1-6. https://doi.org/10.4102/hts.v73i3.4815

Ramantswana, H., 2019, 'Prophets praying for, or preying on people's faith: A reflection on prophetic ministry in the South African context', In die Skriflig/In Luce Verbi 53(4), 1-8. https://doi.org/10.4102/ids.v53i4.2495

Ross, K.R., Asamoah-Gyadu, J.K. \& Johnson, T.M., 2018, Christianity in sub-Saharan Africa, Edinburgh Companions to Global Christianity, EUP, Edinburgh, viewed 11 May 2020, from http://search.ebscohost.com/login.aspx?direct=true\&db=nlebk $\& A N=1923814 \&$ site $=$ ehost-live \&scope $=$ site.

Selge, K.V., 1967, Bd I: Die ersten Waldenser. Bd II: Die ersten Waldenser: mit Edition des Liber Antiheresis des Durandus von Osca, De Gruyter (Arbeiten zur Kirchengeschichte, 37), Berlin.

Tourn, G., 1983, Geschichte der waldenser-kirche: Die einzigartige geschichte einer volkskirche von 1170 bis zur gegenwart, Claudiana, Torino.

Tusting, K., 2004, Congregational studies in the UK: Christianity in a post-Christian context, Taylor \& Francis Group, Florence, viewed 11 May 2020, from ProQuest Ebook Central.

Wakefield, W.L. \& Evans, A.P., 1991, Heresies of the High Middle Ages, Records of western civilization, Columbia University Press, New York, NY. 